О. ФО. Кудрявиев

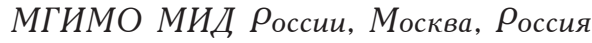

\title{
О НЕКОТОРЫХ СТЕРЕОТИПАХ ВОСПРИЯТИЯ РОССИИ И РУССКИХ В «ЗАПИСКАХ О МОСКОВИИ» СИГИЗМУНДА ГЕРБЕРШТЕЙНА
}

Книга Сигизмунда Герберштейна «Записки о Московии» (1-е изд. - 1549 г.) - самое полное и обстоятельное описание Российской страны, сделанное в Европе в эпоху Возрождения. В ней много нового материала, который ее автор, гуманистически образованный европеец, тем не менее, очень часто использовал для иллюстраџии старых, закоснелых стереотипов восприятия Руси/Московии /

Ключевые слова: Московия, Россия, Герберштейн, гуманизм, эпоха Возрождения, варвары, север, тирания, стереотипь

Работая над «Записками о Московии», Герберштейн, конечно же, задумывался и о вечном. Как добрый католик, он не мог не стремиться к тому, чтобы стяжать жизнь вечную. Но, как сын своего времени, воспитанный на џенностях ренессансной культуры, он не был чужд и желания обрести, так сказать, практическое бессмертие, или неизгладимую известность в веках, хотя нигде открыто в этом не признавался. Да и нужно ли было? Его труд говорил сам за себя. И друзья. Придворный историк и космограф Вольфганг Лаџиус (Wolfgang Lazius), осушествивший вторую латинскую публикаџию «Записок о Московии» в 1551 г. в Базеле у типографа Иоганна Опорина (Хербста), предрекал ему за издание труда «благороднейшего мужа и ученейшего героя» («nobilissimo uiro, doctissimoque Heroe») славу, себе же - бессмертие ${ }^{1}$. А разве сам ренессансный «герой», Герберштейн, был менее этого достоин?

Профессиональный дипломат на службе у Габсбургов, воспринимавший эту свою деятельность как призвание и потому находивший удовольствие, по его собственным словам, в путешествиях и в «обшении с иноземџами», Сигизмунд Герберштейн по поручению своих государей посешал кроме России, в 1517 и 1526 г., и другие страны - неоднократно Венгрию и Польшу, а еше Данию, Испанию, Османскую империю, транзитом же - Италию и Франџию; и он знакомился «не только мимоходом, но и весьма тщательно» со многим в них, что заслуживало бы записи и опубликования. Однако посвятить свой досуг их описанию он не захотел, «отчасти потому, что они были красноречиво и подробно изложены раньше другими, отчасти же потому, что находятся ежедневно на глазах и на виду Европы». И он предпочел посвятить свой труд тому, что не так известно, - «делам московитским, гораздо более скрытым и не столь доступным ознакомлению с ними современников, полагаясь преимушественно на два обстоятельства: на кропотливость своих разысканий и на свое знание славянского языка (linguae Slavonicae peritia)»².

Его не устраивала роль второго плана, но привлекала непременно первостепенная и исключительная. Поэтому он и взялся описывать Русь/ Россию/Московию. В самом деле, кто, кроме него, из ее описателей знал славянский язык, чтобы обшаться с ее жителями? Кто располагал такими же, как и он, сведениями о ней и мог лучше и полнее других о ней рассказать?

Герберштейн, несомненно, амбиџиозен и одновременно смиренен. Однако смирение его, если воспользоваться словами русской поговорки, паче гордости. «Правда, о Московии писали

1 «...mitto interea Commentarios rerum Moscouiticarum, a longe nobilissimo uiro, doctissimoque Heroe, Domino SIGISMVNDO Libero Barone ab Herberstain... concinnatos... Opus mehercule et illud est, quod mihi immortalitatem, et tibi gloriam cum pari commodo coniunctam parere potest» (Herberstain S. Rerum moscoviticarum Commentarij. Basileae, 1551. Sig. a1v).

2 Герберштейн С. Записки о Московии / Под ред. А. А. Хорошкевич (латинский и немеџкий тексты, а также русский перевод). М., 2008. Т. І. С. 24-27.

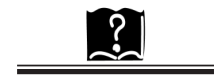


весьма многие, - признается он и тут же добавляет: - но большинство делало это с чужих слов (plerique tamen ex alieno relatu)». Он указывает имена Николая Кузанского (Nicolaus Cusanus), Павла Й Юовия (Paolo Giovio), о котором отзывается с большим уважением как о писателе «красноречивом и очень достоверном», Иоганна Фрабри (Iohannes Fabri), Антония Вида (Antonius Wied) (ошибочно назван, по-видимому, в результате опечатки, как Бид Bied), Олауса Гота (или Mагнуса, Olaus Magnus), Матвея Меховского (Mathias de Miechow), Альберта Кампенского (Albertus Campensis), Себастьяна Мюнстера (Sebastian Münster)³. С тоит заметить, что задолго до Герберштейна, еще в 1523-1525 г., три из указанных им автора Йовий, Фрабри, Альберт Кампенский - посвятили џеликом Московии свои, пусть и небольшие, сочинения и вынесли название этого государства в их заглавие [Кудрявџев, 1997, с. 3]. Однако какими бы достоинствами ни отличались их труды, они, по словам Герберштейна, не могли заставить его отказаться от предпринятого сочинения прежде всего потому, что он в отличие от них был «свидетелем описываемых событий (earum rerum oculatus fuerim testis)» ${ }^{4}$. Вот это его собственное очевидство должно было обесџенить все, что писалось о Руси/ России/Московии до выхода в свет его работы, или по меньшей мере поставить неизмеримо ниже ее. Именно оно должно было обеспечить ему славу истинного первооткрывателя и надежного описателя далекой, как тогда считалось, северной страны. Тому, что Герберштейн стяжал эту славу, может служить доказательством характеристика его как «открывателя России», данная Августом Шлеџером (Augustus Schlözer) в XVIII в. (см.: [Adelung, bd. I, s. 160]).

Џенность своего труда Герберштейн полагал также в том, что иные сведения, сообщенные в нем, он почерпнул «из заслуживающих доверия донесениї», что он «долго и много беседовал при всяком случае о тех (т. е. московитских. - О. К.) делах с очень многими лиџами», гораздо подробнее и пространнее разъяснял то, что другими повествователями о Московии было лишь упомянуто, наконеј, описал то, чего все другие вообе не касались и «что не могло стать известным никому, кроме посла» ${ }^{5}$. И надо признать, он не преувеличивал и действительно необычайно расширил знания европейџев о русском мире.

Однако надо признать и то, что он был не первым очевидџем Руси, описавшим ее. Еше за век до него христолюбивый рыџарь-авантюрист, подданный бургундских герџогов Гильбер де Ланноа дважды, в 1413-1414 и в 1421 г., посешал эту страну и оставил в своих мемуарах «Путешествия и посольства» («Voyages et ambassades») описание Новгорода и Пскова, а также западнорусских земель. В оправдание Герберштейна укажем, что автобиографические записки бургундского рыџаря сохранились в немногочисленных рукописях и никак не могли быть известны габсбургскому дипломату. Более того, их свел в единое џелое из разрозненных заметок уже после смерти самого Гильбера де Аанноа в середине XV в. его капеллан, заметивший во введении, что его набожный патрон этого не сделал из боязни «суетной славы» («vaine gloire») ${ }^{6}$, то есть предосудительной страсти, которая сродни гордыне, страшному греху, препятствуюшему спасению7. Герберштейн подобных страхов уже не знал, он часто и охотно упоминает себя, повествуя о Руси / России / Московии. Прошло сто лет, и мы видим, сколь решительно изменились мировоззренческие установки.

Труд «Путешествие в Персию» («Viaggio in Persia») Амброджо Контарини, еше одного наблюдателя русских земель, увидел свет в 1487 г. В нем автор, венеџианеџ из знатного патриџианского рода, описывал среди прочего свои впечатления от юго-западной, а также

\footnotetext{
3 Там же.

4 Там же. C. $24-27$.

5 Там же.

${ }^{6}$ Lannoy Gh. de. Voyages et ambassades / / Lannoy Gh. de. Oeuvres de Ghillebert de Lannoy, voyageur, diplomate et moralist / Ed. par Ch. Potvin, J. C. Houzeau. Louvain, 1878. P. 9. См. также: [Кудрявџев, 2013, с. 37, 38 ].

${ }_{7}$ См. в этой связи: [Зареџкий, 2002, с. 10-16; Зареџкий, 2009, с. 34-36].
}

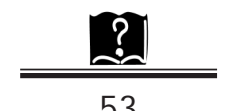


Московской Руси, которую он посетил соответственно в 1474 и 1476-1477 г., выполняя дипломатическую миссию к персидскому шаху. До первой публикаџии книги Герберштейна сочинение Контарини выходило еше дважды, в 1524 и 1543 г. Неизвестно, почему Герберштейн обошел его вниманием. Возможно, он его не знал; возможно, не пожелал называть труд, созданный не на языке высокой науки, то есть не на латыни, а на венеџианском диалекте итальянского, недоступном большей части как людей ученых, так и европейской читающей публики. А может быть, просто не хотел кому-то другому отдавать славу первоописателя-очевидца, на которую он, несомненно, претендовал сам. Да и справедливо это было бы, если иметь в виду, что Герберштейн посвятил Московской Руси огромную, детально характеризуюшую ее с самых разных сторон работу, Контарини - всего несколько страниџ наблюдений среди прочих заметок о многих виденных им странах и народах?! Так-то оно так. И все же Контарини в своем коротеньком репортаже о Российской стране сумел сделать такие зарисовки, какие оказались не по силам даже Герберштейну: Контарини дал наглядный, психологически по-разному нюансированный портрет московского государя Ивана III, словно живую картинку изобразил аудиенџии с ним; он восхишенно писал о зимней торговле на Москве-реке, изображая живописнейший натюрморт в духе фламандџев конџа XVI в. ${ }^{8}$

Наконеџ, был еще один европейский путешественник, посешавший на рубеже $70-80$-х годов XV в. Юго-Западную Русь и писавший об этом, - известный итальянский гуманист Юлий Помпоний Лет (Giulio Pomponio Leto), глава Римской академии и создатель Ватиканской библиотеки. Правда, итинерарий его путешествия утерян, а отдельные заметки о виденном и узнанном на Руси, которые рассеяны по многочисленным комментариям к античным классикам, были выявлены и сведены в некую подборку только в начале $\mathrm{XX}$ в. замечательным русским историком Владимиром Владимировичем Забугиным [Забугин]. Поэтому вопрос о том, почему о нем не упоминает Герберштейн, отпадает сам собой. Есть, однако, обстоятельство, заставляюшее задержать внимание на сведениях о Восточной Европе этого итальянского гуманиста. Принято считать, что первым об отсутствии в Восточной Европе Рифейских и Гиперборейских гор (montes Riphei et Hyperborei), о которых писали античные авторы и в которых будто бы имеют истоки великие реки этого региона, сообшил польский космограф Матвей Меховский (Mathias de Miechow) в «Трактате о двух Сарматиях» («Tractatus de duabus Sarmatiis», 1517 г.) , опиравшийся на сведения, полученные от русских военнопленных ${ }^{10}$. Однако гораздо раньше польского космографа, в 80 -е годы XV в., отвергал эти горы в своих трудах и университетских

\footnotetext{
8 Contarini $A$. Viaggio in Persia / / Скржинская Е. Ч. Барбаро и Контарини о России. К истории итало-русских связей в XV в. ᄉ., 1971. С. 202-206, 226-231.

9 Mathias de Miechow. Tractatus de duabus Sarmatiis Asiana et Europiana et de contentis in eis. Посвятительное письмо; I.III.5; II.I.3; II.II.1; II.II.2 // Матвей Меховский. Трактат о двух Сарматиях / [Подготовка латинского текста,] введение, перевод и комментарии С. А. Аннинского. М.; ․, 1936. С. 46, 84, 110, 116, 118, 128, 163, 186, 192, 194.

10 По утверждению главного оппонента Матвея Меховского императорского посла в Москву Франческо да Колло, во время их очной встречи в Петрокове (1519 г.) в присутствии короля Сигизмунда I польский ученый будто бы утверждал, что сведениями об истоках Дона в Рязанском княжестве он обязан «нескольким пленникам-московитам» (см.: Колло ${ } D_{\rho}$. да. Доношение о Московии / Подготовка текста, перевод на русский язык, вступительная статья и комментарии О. Симчич. М., 1996. С. 51, 64).
}

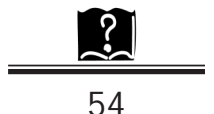


лекџиях Юлий Помпоний Лет ${ }^{11}$. И похоже, именно от него, а не от русских военнопленных воспринял новый взгляд на географию Восточной Европы Матвей Меховский (см.: [Кудрявџев (в печати)]). Ученый мир Европы был потрясен этим, так сказать, «открытием». В пользу нового взгляда и с резкой критикой древних выступили Ульрих фон Гуттен (Ulrich von Gutten), Вилибальд Пиркгеймер (Willibald Pirckheimer), Альберт Кампенский (Albertus Campensis), Павел Йовий (Paolo Giovio) [Кудрявџев (в печати)]. Сам император Максимилиан I, отправляя в 1518 г. новое посольство в Москву, дал ему спеџиальное задание проверить сведения Матвея Меховского. И один из участников этой миссии, Франческо да Колло (Francesco da Collo), в своем донесении утверждал, будто горы эти на самом деле есть и не древние заблуждались на их счет, а польский автор обманывался!'12

Ну а что Герберштейн? Он же, не углубляясь в суть спора, занял компромиссную позиџию.

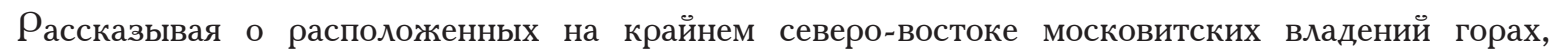
называемых Поясом Мира (Cingulum mundi, сейчас - Уральские горы), Герберштейн замечал,

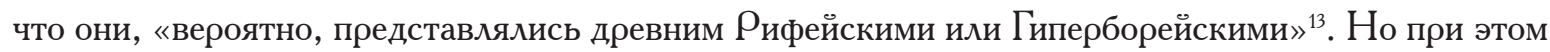
не настаивал на том, что в них берут начало великие реки Сарматий, то есть Дон (Танаис), Днепр (Борисфен) и Волга $\left(\mathrm{Pa}_{\mathrm{a}}\right)$. А ведь именно для объяснения такого происхождения этих

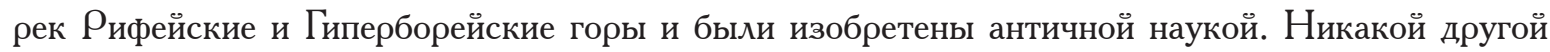
необходимостипредполагать их наличие небыло. Как видим, Герберштейн пытался реанимировать, то есть буквально дать новую жизнь, не просто обветшалой, но и уже благополучно похороненной географической конџепџии.

После сказанного сам собой возникает вопрос: в какой мере Герберштейн следовал сложившейся в европейской литературе традиџии восприятия России? И прежде всего стереотипической ее трактовке как северной страны, населенной варварами? А преимушественно именно так и земли русские, и народ русский описывались византийскими, а затем и европейскими авторами начиная с раннего Средневековья. В русских видели одну из северных, варварских народностей, отождествляемых обычно со скифами, необузданных в своих желаниях, враждебных нравам, воспитанным џивилизаџией, и всякой человечности.

Уже в одном из первых упоминаний в гомилиях (Homiliae) патриарха ФОотия (Photios) в

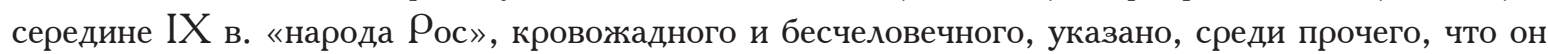
«пришел с севера» (см.: [Кудрявцев, 2011, с. 532]). К северным, скифским народам, наряду с хазарами и турками, относил в середине $\mathrm{X}$ в. росов, то есть русь, византийский император и писатель Константин Багрянородный (Constantinos Porphyrogenetos) в сочинении «Об управлении империей» («De administrando imperio»), предупреждая об их ненасытной алчности ${ }^{14}$. Два столетия спустя, в середине XII в., краковский епископ Матвей (Matthaeus) в послании к знаменитому проповеднику и богослову Бернарду Клервосскому (Bernard de Clairvaux) характеризовал русских как дикий, варварский, лишенный человечности народ, живуший на

11 Дважды, в лекџиях по Валерию Фрлакку и по Вергилию, Помпоний Лет говорил, что Танаис (= Дон) «начинается из болота» («Tanais oritur ex palude»), равно как и Борисфен (= Днепр) (см.: [Забугин, с. 199, 209]). А это значит, что ученые древности - Аристотель, Лукан, Плиний Старший, Помпоний Мела, Солин, Птолемей, а также следовавшие за ними ренессансные землеописатели, как, в частности, ФИлиппо Буонаккорси (известный

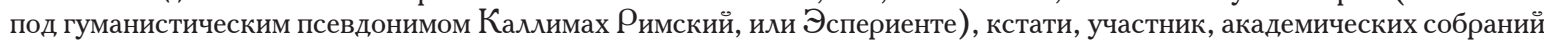
Помпония Лета, ошибались, указывая на некие Рифейские горы, расположенные «за крайней Скифией», как на место, откуда берут начало великие реки Восточной Европы. См. подробнее материал на эту тему в комментариях С. А. Аннинского к изд.: Матвей Меховский. Трактат о двух Сарматиях. С. 203-205. Примеч. 5; а равно комментарии автора настояшей работы к изд.: Альберт Кампенский. О Московии // Россия в первой половине XVI в.: взгляд из Европы / Составитель О. Ф. Кудрявџев. М., 1997. С. 127, 128. См. также соответствуюшее место в «Истории» Каллимаха Эспериенте (80-е годы XV в.): Callimachus Experiens $P$ h. Historia rerum gestarum // Monumenta Poloniae historica. Kraków, 1898. T. VI. P. 21.

${ }_{12}$ Колло $0_{\rho}$. да. Доношение о Московии. С. 49-52, 62-65.

13 Герберштейн С. Записки о Московии. С. 376, 377.

14 См.: [Кудрявџев, 2011, с. 532. Примеч. 3.]

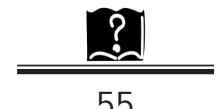


севере, в холодном климате, у «ледяного полюса» ${ }^{15}$. О русских, а равно и о татарах как жителях северных регионов упоминал анонимный описатель Восточной Европы начала XIV в., при этом замечая, что они - варвары и схизматики ${ }^{16}$.

И эти две черты - северное местонахождение и варварские нравы и установления вместе или порознь - стали наиболее устойчивыми стереотипами восприятия и характеристики русских в средневековых и ренессансных документах и сочинениях по космографии.

Для современного европейџа русские, как и татары, а уж тем более турки, - это восточные соседи. Однако в Средние века и в эпоху Возрождения их воспринимали так же, как скифов в древности, то есть как обитателей северных окраин ойкумены. Более того, зачастую просто считали народностями скифского корня. Уже древние мыслители проводили жесткое разграничение между народами, живущими на севере, на юге, с одной стороны, и в срединной части земли - с другой. Первые две категории, подчеркивал Аристотель в «Политике», ушербны в сравнении с теми, кто населяет срединную зону, - эллинами. В частности, люди, обитающие в холодном климате, то есть на севере, пусть и отличаются мужеством и свободолюбием, но обделены умом и способностями к ремеслам, непригодны к государственной жизни и не могут быть господами соседям ${ }^{17}$. Речь идет о своего рода природной заданности того, что можно было бы назвать «наџиональным характером». Эта идея была хорошо усвоена последующими веками. Ее отзвук находим во второй половине XIII в. у Роджера Бэкона (Roger Bacon), одного из светочей средневековой схоластики, рассуждавшего в «Великом труде» («Орus Majus») o зависимости людских нравов от географически обусловленных условий жизни ${ }^{18}$. А другой ее светоч, современник Бэкона Фома Аквинский (Thomas Aquinas) в трактате «О правлении государей» («De regimine principum») џеликом воспроизводит уже џитированное место у Аристотеля, в котором среди прочего речь шла о характерологических особенностях обитателей холодных стран ${ }^{19}$. Два с лишним века спустя прославленный итальянский гуманист Джованни Пико делла Мирандола (Giovanni Pico della Mirandola) в своем труде «Рассуждения против прорицающей астрологии» («Disputationes adversus astrologiam divinatricem») приводил это же положение в качестве незыблемого основания тогдашнего научного знания ${ }^{20}$.

Таким образом, получается, что русские как бы местом своего обитания обречены быть варварами, вместе с другими народами, живущими в холодном климате, представляют особую, северную породу, или расу, в силу неразвитости ума и прочих способностей чуждую џивилизаџии и культуре и даже враждебную истинной вере. То есть они варвары по природе.

Но кроме климата, а возможно, и через него характер народа определяется, как оказывается, действием сил в буквальном смысле более высокого порядка, а именно - астральных. Это положение античной науки было усвоено ренессансной космографией. Вот что писал упомянутый выше польский космограф Матвей Меховский (Mathias de Miechow), старший современник Герберштейна: если рассматривать северные народы с позиџий астрологии, то станет очевидным, что «угол северного аквилона, где ныне находятся татары, принадлежит в подразделении [сферы] к треугольнику северных небесных знаков; в нем господствует Сатурн под знаком

${ }_{15}$ См.: [Кудрявџев, 2011, с. 514, 533, 534.]

16 См.: [Кудрявџев, 2011, с. 534.]

17 Aристотель. Политика. 1327a23-34 // Аристотель. Сочинения. М., 1983. Т. 4. С. 601. См. также: [Кудрявцев, 2011, с. 532, 533].

${ }_{18}$ The Opus Majus of Roger Bacon / Ed. by J. H. Bridges. London, 1897. Vol. I. Р. 250; Матузова В. И. Английские средневековые источники. М., 1979. С. 193, 207.

${ }_{19}$ «Ut enim Aristoteles dicit in sua politica: quae in frigidis locis habitant gentes, sunt quidem plenae animositate, intellectu autem et arte magis deficientes, propter quod libere perseverant magis. Non vivunt autem politice, et vicinis propter imprudentiam principari non possunt...» (Thomas Aquinas. De regimine principum. II. 1 // Thomas Aquinas. Opuscula. Venetiis, 1490. Sig. B1r).

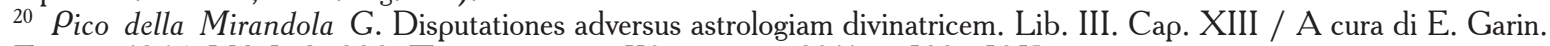
Firenze, 1946. Vol. I. Р. 288. Подробнее см.: [Кудрявцев, 2011, с. 533-535].

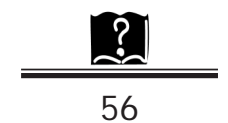


Водолея (Saturnus cum signo Aquarii) и делает названный угол диким и ужасным по характеру его жителей (reddit praefatum angulum ferocem et horrendum secundum incolas eius); так говорит Птолемей (Ptolemaeus)». А еще он говорит - и далее Матвей Меховский почти дословно џитирует первую публикаџию в латинском переводе (Венеџия, 1484 г.) «Четверокнижия» («Тетрабиблоса», по латыни: «Liber quattuor tractatuum») древнегреческого ученого, - что «те, кто находятся на граниџах земель Сарматии и Аскарды, уподобляются Водолею и Сатурну. Оттого они отличаются большей жестокостью и по душевным свойствам весьма дики» ${ }^{21}$.

Но почему эти небесные объекты производят такое злотворное воздействие на людей? Согласно Птолемею, «Сатурну, в характеристике которого преобладает холод... и который движется по наиболее высокой и удаленной от светил орбите, приписываются... [знаки] Козерог и Водолей, причина чего заключена еще в том, что эти знаки холодные и зимние, а их диаметральный аспект несовместим с благотворным влиянием» 22.

На основании подобных положений астрологической науки Матвей Меховский заключал, что «зловредно влияние серпоносного Сатурна (falcifer Saturnus) и чрезвычайно опасно для рода человеческого, действуя всегда против него своими губительными качествами - холодом и сухостью» ${ }^{23}$. И это проклятие звезд тяготеет над всеми народами Севера, в душах которых действием небесных сил взрашены начала, чуждые всякой человечности. «Именно из этого (северного. - О. К.) угла появились и до сего дня являются суровые и жестокие племена, приводяшие в смятение род человеческий. - Предупреждение об этом Матвей Меховский находит и в Библии: - Иеремия в первой главе говорит об этом: “от севера распространится всякое зло на всех обитателей земли” 24 , и всякий, кому угодно будет проверить, найдет это, как божественное изречение, совершенно очевидным и справедливым ${ }^{25}$.

Итак, опираясь на астрологию, выкладки которой считались точными и доказательными значительной частью ученого мира того времени, Матвей Меховский подчеркивал абсолютную зависимость дурных нравственных характеристик уроженџев севера от влияния и положения небесных знаков и тел в данной области земли; в силу этого северянам предопределена свыше только одна роль - выступать как пагуба, своего рода разрушительная стихия, несушая угрозу для сушествования всех других народов.

А это уже приговор. И хотя Матвей Меховский вел речь преимущественно о татарах, к обитателям Севера, как мы помним, относились и русские.

Герберштейн в своем сочинении упоминал о полуночных, или северных, странах не раз, имея в виду прежде всего Московию, которую он посешал дважды ${ }^{26}$. Только упоминал, казалось бы, просто сообшая о географическом положении страны. И ничего более. На самом деле северная локализаџия имела, как мы теперь знаем, џелый ряд обязательных коннотаџий и подразумевала соответствуюшие географической зоне и предсказуемые черты морального облика народа и его общественного быта.

Русские как северяне не могут не быть варварами. По определению. И Герберштейн их изображал таковыми. И никогда не забывал, с кем имеет дело, даже если его русские знакомые

21 «Qui in confinibus terrarum Sarmatiae et terrae Ascardae conversantur, Aquario et Saturno assimilantur. Unde maioris sunt crudelitatis, qualitatesque animarum suarum ferocissimae» (Mathias de Miechow. Tractatus de duabus Sarmatiis Asiana et Europiana et de contentis in eis. I.II.1. C. 149, 68). C $\rho .:$ Ptolemaeus Cl. Liber quattuor tractatuum [Quadripartitum] cum centiloquio et commento Haly. II.4. Venetiis, 1484. Sig. b8v.

22 Птолемей Кл. Тетрабиблос. I.17 / Перевод с английского Г.П. Хлуновской, под редакџией А.А. Капраловой, Н.А. Додоновой. Б.м., б.г. [1992?]. С. 40. В венеџианском издании 1484 г. указан другой номер главы: $\rho_{\text {tolemaeus }}$ Cl. Liber quattuor tractatuum... I.18. Sig. b1v.

${ }_{23}$ Mathias de Miechow. Tractatus de duabus Sarmatiis Asiana et Europiana et de contentis in eis. I.II.1. C. 149, С. 69 (перевод уточнен). См. также комментарий С. А. Аннинского к изд.: Матвей Меховский. Трактат о двух Сарматиях. С. 220. Примеч. 75.

${ }_{24}$ Иер 1: 14. В Синодальном переводе: «от севера откроется бедствие на всех обитателей сей земли».

${ }_{25}$ Mathias de Miechow. Tractatus de duabus Sarmatiis Asiana et Europiana et de contentis in eis. I.II.1. C. 69, 149.

${ }_{26}$ Герберитейн С. Записки о Московии. С. 22, 23. См. также: с. 30, 32.

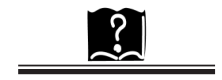


были людьми, заслуживаюшими уважения и симпатии. «Дмитрий Данилович, муж важный и достойный всяческого доверия, - писал Герберштейн об одном из близко известных ему великокняжеских бояр, но тут же не преминул добавить в латинской редакџии: - насколько это возможно у варваров...» ${ }^{27}$. Не стоит эти слова рассматривать как оговорку ${ }^{28}$. Герберштейн сказал то, что имел в виду и что должен был сказать. Оџеним его прямоту.

В других случаях Герберштейн путем очевидного сопоставления или описания подводит читателя в той же самой мысли о варварстве русских, которое заметно у них во всем, начиная с внешнего облика. По его словам, «одежду они носят длинную, шапки белые заостренные, из войлока (lana coacta), из которого... изготовляют себе верхнюю одежду варвары (реnulae barbaricae) $»^{29}$. Под варварами здесь разумелись, конечно же, татары. Но и русские в силу сходства с ними должны напоминать варваров. Дома тоже вызывали недоумение, их сени «достаточно просторны и высоки, а двери низки, так что всякий входяший должен был согнуться и наклониться. Зато пороги высоки», добавлено в немеџкой редакџии. И хотя Герберштейн нашел этому раџиональное и правильное объяснение - так сохраняется тепло в комнатах ${ }^{30}$, подобный тип жилиша должен был представляться европейџу не только неудобным, но и нелепым и неприемлемым, ибо он не подходит свободному человеку, которому не пристало то и дело нагибаться, словно кланяясь.

Какого-либо ошушения достоинства в описании Герберштейна начисто лишены низы обшества, рабочий люд, с которым нельзя обходиться иначе, чем с ленивой рабочей скотиной: поденшики и ремесленники, по словам Герберштейна, «не будут работать усердно, если их хорошенько не побить» («neque hi strenue laborant, nisi bene verberati»). Отчего их отношения с господами имеют немыслимо изврашенный характер: «Я слышал однажды, - свидетельствует Герберштейн, - как слуги жаловались, что господа не побили их как следует. Они считали, что не нравятся своим господам и что те гневаются на них, если не бьют» ${ }^{31}$. Сходно с этим изврашены, в изображении Герберштейна, и отношения между супругами: жена как сушество более слабое и зависимое ожидает и даже требует от мужа битья. Некий немеџкий кузнеџ Иордан, женатый в Москве на русской, будто бы рассказывал габсбургскому дипломату, как его жена жаловалась на то, что он не любит ее, ибо не бьет; в ответ на эти слова Иордан ее крепко поколотил, и жена стала ухаживать за ним с еше большей любовью; он же «упражнялся в этом занятии затем очень часто», так что «сломал ей, наконеџ, шею и ноги». Хотя Герберштейн уточняет, что это произошло в его «бытность в Московии» ${ }^{32}$, тем не менее рассказанное больше напоминает анекдот, который мог быть использован как сюжет для ренессансной новеллы, нежели реальную историю.

Знатные, согласно Герберштейну, держат себя не менее недостойно, нежели простолюдины, но проявляется это иным образом. В частности, какими бы бедными они ни были, считают бесчестным работать собственными руками, но не видят ничего зазорного в том, чтобы «поднимать с земли и поедать корки и шелуху плодов, в особенности дынь, чеснока и лука, брошенного нами или нашими слугами ${ }^{33}$, пишет Герберштейн. Оставим в стороне вопрос о достоверности этих сведений и согласимся с Герберштейном: было бы странно чего-либо иного ожидать от варваров, не ведаюџих правильного гражданского строя и добрых нравов.

27 «Demetrius Danielis, vir (ut inter Barbaros (курсив мой. - О. К.)) grauis ac fide singulari» (Там же. С. 438, 439).

28 А именно так џитированные выше слова предлагается трактовать в работе: [Baron, s. 249].

29 Герберштейн С. Записки о Московии. С. 262-265.

30 Там же.

31 «Audivi servitores aliquando conquestos, quod a dominis non essent probe verberati. Credunt se suis dominis displicere: signumque esse indignationis, si non verberentur» (Там же. С. 264, 265).

${ }_{32}$ Там же. С. 236-239.

33 «Aber des schamen sy sich nit, wan wir oder unsere dienner von frïchtn, als O $\rho f f l$, Piern, Melaun, die schelln verworffen, sy die von der Erden gehebt unnd geessen, auch von den Zwifln die schellen» (Там же. C. 262, 263).

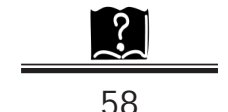


А как может быть правильным гражданский строй у народа, который, по свидетельству Герберштейна, «находит больше удовольствия в рабстве, чем в свободе» ${ }^{34}$ ? Причем речь идет о рабстве не только частном, то есть отдельных лиџ, приобретших рабов разными способами, но о всеобшем, тотальном рабстве всего населения страны. «Все они, - пишет Герберштейн, - называют себя холопами, то есть рабами, государя» ${ }^{35}$. Не стоит сейчас выяснять, означало ли слово «холоп» в данном контексте раба, или, похоже, все-таки подданного. Герберштейн настаивал на первом значении, и мы должны принять его точку зрения. Ибо этим он имеет в виду подчеркнуть всевластие русского монарха, не просто его самодержавие (Autokratie), a что-то не находяшее аналогий даже в восточных деспотиях. Разве как-то иначе можно понять слова: «Властью, которую он (московский государь. - О. К.) имеет над своими подданными, он далеко превосходит монархов џелого мира»? И ниже уточняется характер этой власти: «Всех одинаково гнетет он (тот же московский государь. - О. К.) жестоким рабством...» ${ }^{36}$. Знаками этого всеохватываюшего рабства могут выступать самые неожиданные веши. Так, согласно Герберштейну, хлебы на великокняжеском пиру, имевшие вид лошадиного хомута, то есть калачи, должны были знаменовать «для всех, их вкушающих, тяжкое иго и вечное рабство» ${ }^{37}$.

Используя политический категориальный аппарат своего времени, Герберштейн

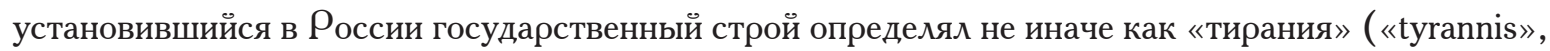
«schwaere Herrschafft», «grausame Herrschafft») ${ }^{38}$. По представлениям образованного европейџа ренессансной поры, хорошо усвоившего классическую политическую доктрину, которая формы правления подразделяла на правильные и неправильные, или изврашенные, тирания принадлежала к числу последних и почиталась самой дурной среди них, будучи вырождением монархической формы, наилучшей среди правильных. Тиранией считалось не самовластье вообше, но лишь такое, которое переходило в полный произвол, попираюший все человеческие законы и божественные установления. Изобразив и ославив порядки Российского государства как тиранические, Герберштейн не только выставил его в дурном свете, но и подводил к мысли о его политико-правовой ушербности, нелегитимности ${ }^{39}$.

Как бывало в других случаях, Герберштейн не первым находил на Руси тиранический государственный строй. Еџе в середине XII в. немеџкий агиограф Герборд в Житии Оттона, епископа Бамбергского, называл тираном Володаря Ростиславича, князя перемышльского, народ русский он описывал не иначе как «жестокий», «суровый», «дикий», «свирепый» (см.: [Кудрявџев, 2011, с. 518]). Но Герберштейн, похоже, был первым, кто устанавливал связь одного с другим - типа власти российского правителя с присущими его народу чертами характера. «Трудно понять, - писал Герберштейн, - то ли народ по своей грубости нуждается в государе-тиране, то ли от тирании государя сам народ становится таким грубым, бесчувственным и жестоким ${ }^{40}$. Герберштейн лукавил, у него есть ответ на поставленный вопрос: народ, предпочитаюший рабство

34 «Gens illa magis servitute, quam libertate gaudet»; «Das volckh ist also naturt, das sy sich der aigenschaft mehr dan der freyhait beruemen» (Там же. C. 238, 239).

35 «Omnes se Principis chlopos, id est servos fatentur»; «Alle im Land nennen sich jres Fürsten Chlopn, das haist verkauffte Knecht» (Там же).

36 «Imperio, quod in suos exercet, omnes facile universi orbis monarchas superat»; «Er uberträff alle Khünig, und Fürsten, mit dem gewalt, den er hette und gebraucht uber die seinigen...»; «omnes iuxta, dura seruitute premit»; «Hellt alle und yede in gleicher dienstparkhait» (Там же. C. 88, 89).

37 «omnibus ijs uescentibus, durum iugum et perpetuam seruitutem designant»; «nach meiner ausslegung die dasselb gemaingelichen geniessen, im herten Joch und schwaerer dienstperkhait dasselb uerdien muessen» (Там же. C. 558, 559 ).

38 Там же. С. $92,93$.

39 Нет никаких оснований соглашаться с $\mathrm{D}_{\rho}$. Кэмпфером, будто «власть Василия III в качестве христианской монархии (als christliche Monarchie) импонировала Герберштейну» [Kaempfer, s. 157].

40 «Incertum est, an tanta immanitas gentis tyrannum principem exigat: an tyrannide Principis, gens ipsa tam immanis, tamque dura crudelisque reddatur»; «Es ist ain zweyfel, ob ain solch uolch ein solche schwaere Herrschafft haben muess, oder ob die grausame Herrschafft ain solch ungeschickht uolckh macht» (Герберштейн С. Записки о Московии. С. 92, 93).

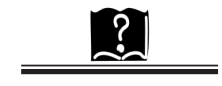


свободе, нуждается в жестоком гнете, обречен на тиранию.

Но ведь и народ не волен в себе. Его характер обусловлен, он зависит от географического местонахождения, от воздействия астральных сил.

А это уже судьба.

$$
* * *
$$

Герберштейна прославляют - и небезосновательно - за то, что он создал широкую детализированную панораму русского мира, позволившую европейџам $\mathrm{c}$ ним ближе познакомиться. Он привел в переводе или в пересказе ряд важных русских документов, в которых освешаются история страны, ее законодательство, религиозные уставы, политический быт. Он дал убедительные, обоснованные ответы на важные для восприятия Руси/ России/ Московии вопросы, о которые «спотыкались» его предшественники, отнеся, в частности, обитателей страны к славянским народам и указав ее пределы от Сарматских (= Карпатских) гор до Северного моря (= Ледовитого океана) с уточнением, что в его время ею владеют три государя: великий князь Московский, великий князь Литовский и король Польский ${ }^{41}$. Однако при этом Герберштейн не порывал с глубоко укоренившейся в европейском сознании, выработанной долгими столетиями и даже тысячелетиями традиџией восприятия земель, на

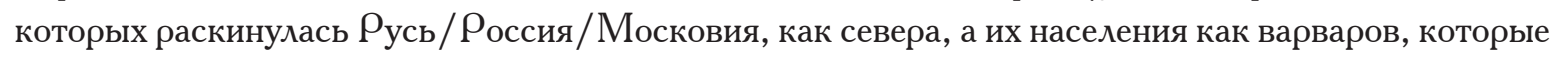
чужды добрым нравам и правильному гражданскому устроению. Более того, этим стереотипам Герберштейн дал новую жизнь, очень выразительно иллюстрируя их умело подобранными или сочиненными картинами русской действительности, которые он развернул и прокомментировал на страниџах своего труда.

«Записки о Московии» - произведение, несомненно, выдающееся; это -дорогой подарок историкам, присланный из глубин ренессансной эпохи; но џенны они не только и даже не столько сведениями о Руси/Московии, которые всегда нуждаются в тшательной проверке и верификаџии, сколько созданным Герберштейном образом этой страны, адресованным и понятным прежде всего людям одной с ним культуры. Именно к ним, их миропониманию и духовному опыту следует обрашаться, изучая сочинение габсбургского дипломата.

\section{Литература}

Забугин В. Юлий Помпоний Лэт. Критическое исследование. СПб., 1914.

Зареикий Ю. П. Автобиографическое «я» от Августина до Аввакума. М., 2002.

Зареикий Ю. П. История субъективности: Средневековая Европа. М., 2009.

Кудрявиев О. ФD. От составителя / / Россия в первой половине XVI в.: взгляд из Европы / Составитель О. Ф. Кудрявцев. М., 1997. С. 3-5.

Кудрявиев О. ФD. «Другой мир»: характерные черты восприятия Руси и русских средневековым Западом // Многоликость џелого: из истории џивилизаџий Старого и Нового Света. Сборник статей в честь Виктора Леонидовича Малькова. М., 2011. С. 508-540.

Кудрявиев О. СD. Западные известия первой половины XV в. о Руси // Европейское Возрождение и русская культура XV - середины XVII в.: контакты и взаимное восприятие. М., 2013. С. 31-67.

Кудрявщев $О . C D$. «Не могу надивиться бесстыдству наших географов»: античная география под судом ренессансного землеведения (в печати).

Adelung Fr. Kritisch-literärische Übersicht der Reisenden in Russland bis 1700, deren Berichte bekannt sind. St. Petersburg; Leipzig, 1846. Bd. I-II.

Baron S. H. Herbersten's Image of Russia and its Transmission through Later Writers // Siegmund Herberstein. Kaiserliche Gesandter und Begründer der Russlandkunde und die europäische Diplomatie / Hg. von G. Pferschy. Graz, 1989. S. 245-273.

Kaempfer Fr. Siegmund von Herbersteins „Rerum Moscoviticarum Commentarii“ als religionsgeschichtliche Quelle // Siegmund von Herberstein. Kaiserliche Gesandter und Begruender Russlandkunde und europaeische Diplomatie. Graz, 1989. S. 147-163.

41 Там же. С. 34-41.

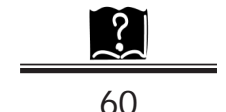




\begin{abstract}
Oleg F. Kudryavtsev
Moscow State Institute of International Relations (University) of the Ministry of Foreign Affairs Russian Federation, Moscow, Russia

SOME STEREOTYPES OF PERCEPTION OF RUSSIA IN SIGISMUND HERBERSTEIN'S “RERUM MOSCOVITICARUM COMMENTARII"

The Herberstein's work "Rerum Moscoviticarum commentarii" (1 $1^{\text {st }}$ ed. - 1549) is the most full and comprehensive description of Russia made in the Renaissance Europe. It contains a lot of new material, which the author, the humanistically educated European, mainly used nevertheless to illustrate the old, obdurate stereotypes of perception the Rus' /Muscovy/ Russia formed in the previous centuries.

Keywords: Muscovy, Russia, Herberstein, humanism, the Renaissance, barbarians, the North, tyranny, stereotypes
\end{abstract}

